\title{
PRINSIP PENGENALAN MORFEM DALAM BAHASA INGGRIS: KAJIAN MORFOLOGI
}

\author{
(Recognition Principles of English Morphemes: A Morphology Study)
}

\author{
Suhila Mahamu, Agus Nero Sofyan \\ Fakultas Ilmu Budaya Universitas Padjadjaran \\ Jalan Raya Bandung-Sumedang Km. 21, Sumedang, Jawa Barat 45363 \\ Pos-el: suhila20001@mail.unpad.ac.id
}

(Naskah Diterima 26 Januari 2021—Direvisi 29 September 2021—Disetujui 14 Oktober 2021)

\begin{abstract}
This research aims to classify and identify morphemes recognition in English. The method used in this study is qualitative descriptive method. In providing data, the researcher uses listening and note-taking technique. The data used in this study were retrieved from the book Top Grammar: A Guide to Write English. While the theory used is the theory of the principle of morpheme recognition. The results of this discussion can be classified into six principles of morpheme recognition namely (1) the form of indefinite pronouns, comparative and superlative degree and reflexive pronouns; (2) singular and plural forms; (3) the form of the past participle in regular $\{-d\} /\{-e d\}$ and irregular $\{-n\}$ forms; (4) singular and plural nouns, present and past verbs; (5) the form of homonyms and in principle; and (6), the form of free morpheme and bound morpheme. From the results of the classification, morpheme units can be identified based on word form, word class and also the meaning that appears.
\end{abstract}

Keywords: English, morpheme, morphology, principle

\begin{abstract}
Abstrak
Penelitian ini bertujuan untuk mengklasifikasi dan mengidentifikasi pengenalan morfem dalam bahasa Inggris. Metode yang digunakan dalam penelitian ini adalah metode deskriptif kualitatif. Dalam tahapan penyediaan data, penulis menggunakan teknik simak dan catat. Data yang digunakan dalam penelitian ini bersumber dari buku Top Grammar: A Guide to Write English. Teori yang digunakan adalah teori prinsip pengenalan morfem. Hasil dari pembahasan menunjukan bahwa terdapat enam prinsip pengenalan morfem, yaitu (1) terdapat pada bentuk indefinite pronoun, comparative dan superlative degree, serta reflexive pronoun; (2) terdapat pada bentuk tunggal dan jamak; (3) terdapat data pada bentuk past participle bentuk regular $\{-d\}\}$-ed $\}$ dan irregular $\{-n\} ;$ (4) terdapat pada kata benda tunggal dan jamak dan kata kerja present serta past; (5) terdapat pada bentuk homonim; (6) terdapat pada bentuk morfem bebas dan terikat. Dari hasil klasifikasi tersebut dapat disimpulkan bahwa satuan morfem dapat diidentifikasi berdasarkan bentuk kata, kelas kata, dan makna yang muncul.
\end{abstract}

Kata kunci: bahasa Inggris, morfem, morfologi, prinsip

\section{PENDAHULUAN}

Bahasa merupakan alat komunikasi terbaik yang hanya dimiliki oleh manusia. Dengan adanya bahasa, manusia berinteraksi dengan sesama. Dalam komunikasi bahasa mempunyai beberapa fungsi, yaitu fungsi sebagai informasi, ekspresi, adaptasi, dan sosial kontrol (Keraf, 1991).

Bahasa memiliki begitu banyak hubungan dengan berbagai kehidupan manusia sehingga bahasa dapat dipelajari 
dari berbagai sudut pandang (Gleason, 1995). Sementara itu, kajian ilmiah bahasa disebut linguistik. Linguistik merupakan ilmu yang memberi pemahaman kepada manusia tentang seluk-beluk bahasa (Lyons, 1968).

Menurut Chaer (2017) setiap kegiatan yang bersifat ilmiah tentu mempunyai objek. Begitu juga dengan linguistik yang mengambil bahasa sebagai objeknya. Linguistik merupakan ilmu yang menelaah asas-asas umum yang berlaku pada bahasa secara universal. Sementara itu, Verhaar (2016) menjelaskan bahwa linguistik adalah ilmu bahasa dan merupakan nama bidang ilmu yang bersifat linguistis atau linguistik.

Dalam penelitian ini penulis akan memfokuskan salah satu kajian dari linguistik, yaitu morfologi. Bauer (2007) mendefinisikan linguistik sebagai pembelajaran dari semua fenomena yang berkaitan dengan bahasa, baik strukturnya, penggunaannya, maupun implikasinya. Salah unsur ilmu bahasa adalah morfologi, yaitu ilmu yang berkaitan dengan struktur internal kata-kata.

Sementara itu, Nida (1970) menyatakan bahwa morfologi merupakan suatu kajian yang mempelajari tentang morfem dan susunannya dalam membentuk kata. Morfologi mempelajari morfem, morfem tersebut dibentuk menjadi kata atau morfem kompleks. Morfem sendiri merupakan satuan bunyi bahasa yang terkecil yang mengandung arti atau ikut mendukung arti. Menurut Keraf (1984:51), morfologi adalah bagian dari tata bahasa yang membicarakan bentuk kata. Secara etimologis, morfem berasal dari bahasa Yunani morph 'bentuk'. Dalam bahasa Inggris, morph- berarti bentuk. Dalam ilmu linguistik istilah morfologi dipakai untuk menyebut sistem mental yang terlibat dalam pembentukan kata atau cabang ilmu linguistik yang berkenaan dengan kata, struktur internal kata, dan pembentukan kata. Dalam ilmu linguistik istilah morfologi dipakai untuk menyebut sistem mental yang terlibat dalam pembentukan kata atau cabang ilmu linguistik yang berkenaan dengan kata, struktur internal kata, dan bagaimana kata tersebut dibentuk. (Aronoff \& Fudeman, 2005).

Yule (2016) menjelaskan bahwa morfologi merupakan cabang ilmu linguistik yang mempelajari seluk beluk sebuah morfem. Katamba (1993) menjelaskan bahwa morfologi adalah ilmu yang mempelajari struktur kata, dan morfem adalah satuan makna terkecil.

Hockett (dalam Tarigan, 1988) juga mengemukakan bahwa morfem adalah unsur yang terkecil yang secara individual mengandung pengertian dalam ujaran sesuatu bahasa. Morfem sebagai satuan gramatikal terkecil memberikan kontribusi yang sangat besar dalam hal pembentukan kata (Puspita, 2020). Crystal (dalam Ba'dulu \& Herman, 2005) mengatakan bahwa morfologi adalah cabang tata bahasa yang menelaah struktur atau bentuk kata, utamanya melalui penggunaan morfem.

Achmad, H.P. dan Abdullah (2012) berpendapat bahwa morfologi adalah bagian dari ilmu kebahasaan yang mempelajari struktur internal kata, tata kata, atau tata bentuk. Morfologi mengkaji unsur dasar atau satuan terkecil dari suatu bahasa. Satuan terkecil atau satuan gramatikal terkecil disebut morfem.

Dengan definisi yang telah disebutkan sebelumnya dapat disimpulkan bahwa morfem merupakan unit terkecil dan bermakna, tetapi tidak jarang yang masih merasa kesulitan untuk mengidentifikasi sebuah morfem. Berdasarkan hal itu, supaya lebih mudah untuk mengenali satuan morfem, ada beberapa pendapat mengenai prinsipnya. Samsuri (1994) dalam buku Analisis Bahasa mengemukakan cara mengenal morfem secara umum dengan memberi contoh dalam berbagai bahasa. Salah satunya bahasa Inggris yang 
didasarkan atas tiga prinsip pokok berikut. Prinsip pertama, bentuk-bentuk yang berulang yang mempunyai pengertian yang sama, termasuk morfem yang sama. Prinsip kedua, bentuk-bentuk yang mirip susunan fonem-fonemnya, yang mempunyai pengertian yang sama, termasuk morfem yang sama apabila perbedaannya dapat diterangkan secara fonologis. Prinsip ketiga, bentuk-bentuk yang berbeda susunan fonem-fonemnya, yang tidak dapat diterangkan secara fonologis perbedaanperbedaannya, masih dapat dianggap sebagai alomorf-alomorf dari morfem yang sama atau mirip asal perbedaan-perbedaan itu dapat diterangkan secara morfologis.

Sementara itu, ada tiga prinsip tambahan yang merupakan kesimpulan dari prinsip pokok. Prinsip pertama, bentukbentuk yang sebunyi (homofon) merupakan (1) morfem-morfem yang berbeda apabila berbeda pengertiannya, (2) morfem yang sama apabila pengertiannya yang berhubungan (atau sama) diikuti oleh distribusi yang berlainan, dan (3) morfemmorfem yang berbeda karena meskipun pengertiannya berhubungan, distribusinya sama. Prinsip kedua, suatu bentuk dapat dinyatakan sebagai morfem apabila (1) berdiri sendiri, (2) merupakan perbedaan yang formal di dalam suatu deretan struktur, (3) terdapat di dalam kombinasi-kombinasi dengan unsur lain yang dapat berdiri sendiri atau di dalam kombinasi-kombinasi yang lain pula. Prinsip ketiga, jika suatu bentuk terdapat di dalam kombinasi-kombinasi dengan bentuk lain yang pada gilirannya dapat berdiri sendiri atau di dalam kombinasi dengan bentuk-bentuk lain, bentuk itu dianggap morfem. Jika di dalam suatu deretan struktur terdapat perbedaan yang tidak merupakan bentuk, tetapi kekosongan, kekosongan itu dianggap sebagai (1) morfem tersendiri apabila deretan struktur itu berurutan dengan morfem-morfem, dan (2) alomorf dari suatu morfem apabila deretan struktur itu berurutan dengan alomorf-alomorf suatu morfem.

Pendapat lain diungkapkan oleh Nida (1949). Ia mengatakan ada enam prinsip yang dapat digunakan untuk mengidentifikasi morfem suatu bahasa. Prinsip pertama, bentuk-bentuk yang memiliki makna yang sama dan bentuk fonemik yang identik dalam semua kemunculannya merupakan satu morfem. Prinsip kedua, bentuk-bentuk yang memiliki arti yang sama dengan struktur fonem-fonem yang berbeda, satuansatuan itu masih dianggap sebagai morfem yang sama selama perbedaan struktur fonem-fonem dapat dijelaskan secara fonologis. Prinsip ketiga, bentukbentuk yang memiliki makna yang sama, tetapi berbeda dalam urutan fonemfonemnya, meskipun perbedaan distribusinya tidak dapat ditentukan secara fonologis, masih dianggap sebagai satu morfem apabila satuan-satuan itu mempunyai distribusi yang komplementer berdasarkan batasan-batasan kemunculan dalam deret struktur yang sama mendahului kemunculan pada deret struktur yang berbeda dalam penentuan status morfemik, (2) distribusi komplementer dalam deret struktur yang berbeda membentuk basis untuk menggabungkan alomorf-alomorf menjadi satu morfem yang termasuk dalam kelas distribusi yang sama dengan deret alomorfik yang bersangkutan dan hanya mempunyai satu alomorf atau alomorf yang dapat ditentukan secara fonologis, (3) lingkungan taktis terdekat mendahului lingkungan taktis jauh dalam menentukan status morfem, (4) kontras dalam lingkungan distribusional yang sama dapat diperlakukan sebagai submorfemis jika perbedaan dalam makna alomorf menggambarkan distribusi bentuk-bentuk itu. Prinsip keempat, perbedaan bentuk yang nyata atau perbedaan yang ditunjukan pada fonem atau urutan fonem dalam deretan 
struktur merupakan morfem apabila dalam deretan struktur suatu satuan berparalel dengan suatu kekosongan. Kekosongan itu merupakan morfem yang termasuk ciri penting untuk membedakan unit minimal dari persaman fonetiksemantik yang disebut morfem zero. Prinsip kelima, bentuk-bentuk yang mempunyai struktur fonologis yang sama mungkin merupakan satu morfem, mungkin pula merupakan morfem yang berbeda berdasarkan persyaratan (1) bentuk-bentuk homofon dengan makna yang jelas berbeda merupakan morfem yang berbeda, (2) bentuk-bentuk homofon dengan makna yang berhubungan merupakan morfem yang sama apabila kelas-kelas makna disejajarkan dengan perbedaan distribusi, tetapi dapat pula merupakan morfem yang berbeda apabila kelas-kelas makna tidak disejajarkan oleh perbedaan distribusi. Prinsip keenam, suatu morfem dapat dipisahkan jika morfem itu muncul dalam kondisi-kondisi berikut (1) berdiri sendiri, (2) dalam beberapa kombinasi yang setidaknya satu di antara satuan yang digabungkan terjadi secara terpisah atau dalam kombinasi lain, (3) dalam kombinasi tunggal, asalkan unsur yang digabungkan dapat berdiri sendiri atau dalam kombinasi lain dengan konstituen yang tidak unik.

Berdasarkan pembahasan di atas, penulis memfokuskan penelitian ini pada prinsip pengenalan morfem bahasa Inggris. Bahasa Inggris merupakan salah satu bahasa yang eksistensinya semakin penting (Budiarti, 2012). Oleh karena itu, penelitian ini bertujuan untuk mengidentifikasi dan mengklasifikasi satuan morfem bahasa Inggris yang terkandung dalam buku Top Grammar: A Guide to Write English.

\section{METODE PENELITIAN}

Menurut Sudaryanto (2018), metode merupakan cara yang harus dilaksanakan atau diterapkan, sedangkan teknik ialah cara melaksanakan atau menerapkan metode tersebut. Metode yang digunakan dalam penelitian ini adalah metode deskriptif kualitatif. Metode tersebut merupakan metode penelitian yang mendeskripsikan gejala atau fenomena kebahasaan seperti apa adanya.

Menurut Djajasudarma (2010), metode penelitian kualitatif merupakan sebuah metode yang menghasilkan data secara deskriptif dalam masyarakat bahasa. Data itu dapat berbentuk data tertulis atau lisan. Metode deskriptif adalah metode yang bertujuan mendeskripsikan atau menggambarkan data secara faktual.

Prosedur yang digunakan dalam penelitian ini adalah penyediaan data, analisis data, dan penyajian hasil. Dalam tahapan penyediaan data, peneliti menggunakan metode simak. Menurut Mahsun (2017), metode simak merupakan metode yang digunakan untuk memperoleh data dengan cara menyimak pemelajaran bahasa yang tidak hanya berkaitan dengan penggunaan bahasa lisan, tetapi juga tertulis.

Adapun data yang dikumpulkan oleh peneliti merupakan kosakata dalam buku panduan tata bahasa Inggris Top Grammar: A Guide to Write English yang ditulis oleh Suherman (2018). Buku itu membahas materi dari dasar sampai mahir dengan penyajian yang sistematis dengan bahasa dan contoh-contoh yang praktis sehingga mudah dipahami.

Teknik catat dilakukan setelah teknik simak. Menurut Mahsun (2017), teknik catat merupakan teknik lanjutan dari metode simak. Teknik catat digunakan dalam penelitian ini untuk mengidentifikasi dan mengklasifikasi data.

Dalam tahap pengumpulan data peneliti menggunakan beberapa tahapan, di antaranya (1) membaca dan menyimak kosakata dalam buku panduan tata bahasa 
Inggris, (2) memahami makna dari kosakata dalam buku panduan tata bahasa Inggris Top Grammar: A Guide to Write English secara mendalam, (3) mencatat dan mengklasifikasikan data sesuai dengan prinsip pengenalan morfem berdasarkan teori Nida (1970). Teknik analisis data yang digunakan dalam penelitian ini adalah teknik deskriptif dengan cara menganalisis bagian-bagian yang menjadi indikator yang akan diteliti, yaitu prinsip pengenalan morfem berdasarkan teori Nida (1970).

\section{PEMBAHASAN}

\section{Klasifikasi Prinsip Pengenalan Morfem}

Dalam pembahasan ini peneliti mengklasifikasi data berdasarkan teori prinsip pengenalan morfem oleh Nida (1949).

\section{Prinsip I}

Bentuk yang termasuk dalam prinsip I ditemukan pada indefinite pronoun, comparative, superlative, dan reflexive pronoun. Perhatikan tabel berikut.

Tabel 1 Indefinite Pronouns

\begin{tabular}{lllll}
\hline No. & Kata & \multicolumn{2}{c}{ Morfem } & Arti \\
\hline 1. & one & no & one & $\begin{array}{l}\text { tidak ada } \\
\text { seorang } \\
\text { pun }\end{array}$ \\
\hline & nobody & no & body & $\begin{array}{l}\text { tidak ada } \\
\text { seorang } \\
\text { pun }\end{array}$ \\
\hline & nothing & no & thing & $\begin{array}{l}\text { tidak ada } \\
\text { apa-apa }\end{array}$ \\
\hline 2. & everyone & every & one & $\begin{array}{l}\text { setiap } \\
\text { orang }\end{array}$ \\
\hline & everybody & every & body & $\begin{array}{l}\text { setiap } \\
\text { orang }\end{array}$ \\
\hline & everything & every & thing & semuanya \\
\hline 3. & anyone & any & one & $\begin{array}{l}\text { setiap } \\
\text { orang }\end{array}$ \\
\hline & anybody & any & body & $\begin{array}{l}\text { setiap } \\
\text { orang }\end{array}$ \\
\hline & anything & any & thing & sesuatu \\
\hline
\end{tabular}

Prinsip I dapat ditemukan pada kategori indefinite pronoun, yaitu pada rangkaian kata no one, nobody, nothing, everyone, everybody, everything, anyone, anybody, dan anything. Prinsipnya, bentuk seperti no yang dilekatkan pada kata benda, seperti no one, nobody, dan nothing, merupakan morfem yang sama. Ia selalu memiliki bentuk fonetik dan makna yang sama, tidak ada. Demikian pula bentuk every dalam rangkaian kata everyone, everybody, dan everything merupakan morfem yang sama karena memiliki bentuk fonetik dan makna yang sama, yaitu setiap. Bentuk any dalam anyone, anybody, dan anything juga demikian. Bentuk every dan any memiliki makna yang pada dasarnya sama, yaitu setiap. Bentuk every dan any tidak memiliki bentuk fonetik yang sama sehingga dapat dikatakan bahwa kedua morfem tersebut merupakan morfem yang berbeda. Demikian pula dengan bentuk kata benda, seperti one, body, dan thing, yang selalu muncul di belakang bentuk no, every, dan any merupakan morfem yang berbeda. Ada pula bentuk body dalam rangkaian kata nobody, everybody, dan anybody. Bentuk body yang muncul merupakan morfem yang sama. Bentuk body selalu memiliki bentuk fonetik dan makna yang sama. Bentuk thing dalam rangkaian kata nothing, everything, dan anything merupakan morfem yang sama.

Tabel 2 Comparative Degree $\{$-er $\}$ dan Superlative Degree $\{$-est $\}$

\begin{tabular}{lllll}
\hline No. & Kata & \multicolumn{2}{c}{ Morfem } & Arti \\
\hline 1. & richer & rich & $-e r$ & $\begin{array}{l}\text { lebih } \\
\text { kaya } \\
\text { dari }\end{array}$ \\
\hline & & & & $\begin{array}{l}\text { lebih } \\
\text { besar } \\
\text { dari }\end{array}$ \\
\hline & greater & great & $-e r$ & $\begin{array}{l}\text { lebih } \\
\text { tinggi }\end{array}$ \\
\hline taller & tall & $-e r$ & $\begin{array}{l}\text { paling } \\
\text { murah }\end{array}$ \\
\hline & cheapest & cheap & - est & paling \\
& & & & pendek \\
\hline
\end{tabular}




\begin{tabular}{llll}
\hline richest & rich & -est & kaya \\
\hline greater & great & -est & besar \\
\hline tallest & tall & -est & tinggi \\
\hline
\end{tabular}

Pada tabel 2, bentuk $\{$-er $\}$ yang menunjuk kata sifat komparatif lebih...dari, seperti cheaper, shorter, dan richer, merupakan morfem yang sama karena berfungsi sebagai penanda makna komparatif. Namun, bentuk $\{$-er $\}$ yang melekat pada kata kerja biasanya bermakna tindakan. Demikian pula pada kata cheapest, shortest, richest, greatest, dan tallest. Bentuk \{-est\} pada rangkaian tersebut dapat dikatakan sebagai morfem yang sama karena memiliki bentuk fonetik yang sama dan memiliki makna yang pada dasarnya sama, yaitu 'paling' sebagai penanda dari bentuk superlative degree. Kata dasar cheap, short, rich, great, dan tall beserta bentukannya pada nomor 1 dan 2 merupakan morfem yang sama karena memiliki bentuk fonetik dan makna yang sama pula.

Tabel 3 Reflexive Pronouns

\begin{tabular}{lllll}
\hline No. & Kata & \multicolumn{2}{c}{ Morfem } & \multicolumn{1}{c}{ Arti } \\
\hline 1. & myself & my & self & saya sendiri \\
\hline & yourself & your & self & anda sendiri \\
\hline & herself & her & self & $\begin{array}{l}\text { dirinya } \\
\text { sendiri } \\
\text { (perempuan) }\end{array}$ \\
\hline & & & self & $\begin{array}{l}\text { dirinya } \\
\text { sendiri } \\
\text { (lelaki) }\end{array}$ \\
\hline & himself & him & & itu sendiri \\
\hline 2. & themselves & them & selves & $\begin{array}{l}\text { mereka } \\
\text { sendiri }\end{array}$ \\
\hline & ourselves & our & selves & kita sendiri \\
\hline
\end{tabular}

Prinsip I terdapat pula dalam reflexive pronoun. Morfem \{-self\} dalam rangkaian myself, yourself, herself, himself, dan itself merupakan morfem yang sama karena memiliki bentuk fonetik dan makna dasar yang sama, yaitu menunjukkan kepemilikan diri sendiri dalam bentuk tunggal. Demikian pula $\{$ selves\} pada kata themselves dan ourselves yang menunjukkan makna kepemilikan diri sendiri dalam bentuk jamak.

\section{Prinsip II}

Bentuk yang termasuk dalam prinsip ini terdapat pada bentuk tunggal dan jamak. Perhatikan tabel berikut.

Tabel 4 Bentuk Jamak $\{-s\} /\{-e s\}$

\begin{tabular}{|c|c|c|c|}
\hline No. Morfem & $\begin{array}{l}\text { Bentuk } \\
\text { Jamak }\end{array}$ & Bunyi & Arti \\
\hline \multirow[t]{5}{*}{ 1. $\{-s\}$} & books & /buk/s/ & $\begin{array}{l}\text { buku- } \\
\text { buku }\end{array}$ \\
\hline & pants & /pænt/s/ & $\begin{array}{l}\text { celana- } \\
\text { celana }\end{array}$ \\
\hline & shorts & $/ \int \mathfrak{s : t / s} /$ & $\begin{array}{l}\text { celana- } \\
\text { celana } \\
\text { pendek }\end{array}$ \\
\hline & proofs & /pru:f/s/ & $\begin{array}{l}\text { bukti- } \\
\text { bukti }\end{array}$ \\
\hline & safes & /serf/s/ & $\begin{array}{l}\text { lemari- } \\
\text { lemari } \\
\text { besi }\end{array}$ \\
\hline \multirow[t]{8}{*}{ 2. $\{-s\}$} & hand $s$ & /hænd/z/ & $\begin{array}{l}\text { tangan- } \\
\text { tangan }\end{array}$ \\
\hline & tables & /'terbl/z/ & $\begin{array}{l}\text { meja- } \\
\text { meja }\end{array}$ \\
\hline & trees & /tri:/z/ & $\begin{array}{l}\text { pohon- } \\
\text { pohon }\end{array}$ \\
\hline & boys & /bor/z/ & $\begin{array}{l}\text { anak- } \\
\text { anak } \\
\text { lelaki }\end{array}$ \\
\hline & days & /deI/z/ & hari-hari \\
\hline & keys & /ki:/z/ & $\begin{array}{l}\text { kunci- } \\
\text { kunci }\end{array}$ \\
\hline & jean $s$ & /dzi:n/z/ & $\begin{array}{l}\text { celana- } \\
\text { celana } \\
\text { jeans }\end{array}$ \\
\hline & photos & /' fəutəu/z/ & $\begin{array}{l}\text { foto- } \\
\text { foto }\end{array}$ \\
\hline \multirow[t]{6}{*}{ 3. $\{-e s\}$} & buses & /bıs/əz/ & bus-bus \\
\hline & classes & /kla:s/ əz/ & $\begin{array}{l}\text { kelas- } \\
\text { kelas }\end{array}$ \\
\hline & boxes & /bpks/əz/ & $\begin{array}{l}\text { kotak- } \\
\text { kotak }\end{array}$ \\
\hline & quizzes & /kwIz/əz/ & $\begin{array}{l}\text { ulangan- } \\
\text { ulangan }\end{array}$ \\
\hline & benches & /bentf/ əz/ & $\begin{array}{l}\text { bangku- } \\
\text { bangku }\end{array}$ \\
\hline & brushes & 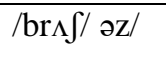 & $\begin{array}{l}\text { sikat- } \\
\text { sikat }\end{array}$ \\
\hline
\end{tabular}


Dalam bahasa Inggris penanda jamak memiliki lebih dari satu bentuk. Perbedaan antara dua bentuk tersebut dapat dijelaskan secara fonologis, yaitu pada rangkaian kata books, pants, shorts, proofs, safes, hands tables, trees, boys, days, keys, jeans, photos buses, classes, boxes, quizzes, dan benches.

Bentuk tersebut memiliki struktur fonologis berbeda. Pada data 1 terdapat akhiran $\{-s\}$ dalam kata books, pants, shorts, proofs, safes, dan hands. Pada data 2 akhiran $\{-s\}$ berbunyi $\{-z\}$ dalam tables, trees, boys, days, keys, jeans, dan photos. Data 3 akhiran $\{-e s\}$ berbunyi $\{-$ iz\} dalam buses, classes, boxes, quizzes, dan benches. Bentuk tersebut memiliki struktur fonologis yang berbeda, tetapi memiliki makna yang sama. Bentuk $\{-s\}$ dan $\{$-es\} memiliki kesamaan makna dan memiliki struktur fonetik atau urutan fonem yang dapat ditentukan oleh jenis konsonan atau fonem di akhir kata tersebut.

Bunyi $\{-s\}$ atau $\{-e s\}$ dalam bahasa Inggris dapat diucapkan dengan tiga bunyi yang berbeda, yaitu /s/, /z/, dan /iz/. Perbedaan dalam pengucapannya dapat dijelaskan secara fonologis, yaitu (a) dilafalkan dengan bunyi $/ s /$ apabila melekat pada kata-kata yang berakhiran voiceless consonants $/ \mathrm{p} / \mathrm{l} / \mathrm{t} / \mathrm{l} / \mathrm{k} /$, dan $/ \mathrm{f} /$; (b) dilafalkan dengan bunyi /z/ apabila melekat pada kata-kata yang berakhiran voiced consonants atau konsonan bergetar $/ b /, / d /, / g /, / l /, / r /, / w /, / m /, / n /$, $/ v /$, dan $/ y /$; dan (3) dilafalkan dengan bunyi /iz/ apabila melekat pada kata-kata yang berakhiran bunyi mendesis $/ t f /, / d z /$, $/ s /$, dan $/ z /$.

\section{Prinsip III}

Bentuk yang termasuk dalam prinsip ini terdapat pada bentuk past participle. Perhatikan tabel berikut.
Tabel 5 Regular Past Participle $\{-d\} /\{-e d\}$ dan Irregular $\{-n\}$

\begin{tabular}{|c|c|c|c|c|c|}
\hline No. & Morf. & Inf. & Regular & Irregular & Arti \\
\hline \multirow[t]{4}{*}{1.} & $\begin{array}{l}-d / \\
-n\end{array}$ & shave & shaved & shaven & mencukur \\
\hline & & strewe & strewed & strewn & menaburkan \\
\hline & & prove & proved & proven & membuktikan \\
\hline & & wake & waked & waken & bangun \\
\hline \multirow[t]{7}{*}{2.} & $\begin{array}{l}-e d / \\
-n\end{array}$ & hew & hewed & hewn & menebang \\
\hline & & mow & mowed & mown & $\begin{array}{l}\text { memotong } \\
\text { rumput }\end{array}$ \\
\hline & & saw & sawed & sawn & menggergaji \\
\hline & & sew & sewed & sewn & menjahit \\
\hline & & show & showed & shown & menunjukan \\
\hline & & sow & sowed & sown & menyebarkan \\
\hline & & strew & strewed & strewn & menaburkan \\
\hline
\end{tabular}

Yang dimaksud dengan distribusi komplementer adalah perbedaan bentuk yang disejajarkan dengan perbedaan distribusi. Prinsip ini terdapat dalam bentuk past participle yang merupakan bentuk kata kerja ketiga. Dalam bahasa Inggris bentuk past participle terdiri atas dua bentuk, yaitu regular dan irregular. Bentuk regular merupakan bentuk perubahan kata kerja yang beraturan, biasanya berakhiran $\{-d\} /\{-e d\}$, sedangkan bentuk irregular merupakan bentuk perubahan kata kerja yang tidak beraturan. Kedua bentuk memiliki kekhasan semantik atau makna yang sama, yaitu digunakan untuk menentukan bentuk perubahan kata kerja ketiga yang menunjuk pada aktivitas yang bersifat pasif. Namun, kedua bentuk tersebut memiliki struktur fonologis yang berbeda. Bentuk regular past participle yang berakhiran dengan $\{-d\} /\{-e d\}$ dan bentuk irregular past participle termasuk dalam rangkaian struktur yang sama, yaitu rangkaian bentuk yang berhubungan secara struktural karena memiliki ciri-ciri umum yang sama. Batasan-batasan prinsip itu ialah (1) bentuk-bentuk yang berakhiran $\{-d\} /\{$ ed\} dan $\{-n\}$ memiliki unsur-unsur pembentukan kata yang tidak identik, tetapi memiliki struktur yang sama, yaitu 
menentukan ciri-ciri umum pada kata kerja ketiga atau past participle; (2) perbedaan distribusi regular past participle yang berakhiran $\{-d\} /\{-e d\}$ dapat diterangkan secara fonologis, tetapi perbedaan distribusi antara regular past participle $\{-d\} /\{$-ed $\}$ dan bentuk irregular $\{-n\}$ tidak dapat dijelaskan karena merupakan distribusi komplementer; (3) menentukan status morfemik lebih diutamakan dengan mengidentifikasi lingkungan taktis langsung, yaitu mengidentifikasi konstruksi langsung pada setiap morfem, daripada lingkungan taktis tidak langsung. Sebagai contoh, rangkaian kata shaved, strewed, proved, dan waked merupakan lingkungan taktis langsung $\{$-ed $\}$ dari bentuk dasar shave, strewe, prove, dan wake, sedangkan bentuk was dan were dalam was shaved, was strewed, ware proved, dan were waked merupakan lingkungan taktis tidak langsung dari $\{-d\}$; (4) karena bentuk regular yang berakhiran $\{-d\} /\{-e d\}$ dan bentuk irregular yang berakhiran $\{-n\}$ memiliki urutan fonem yang berbeda dari bentuk past participle, kedua bentuk tersebut dianggap sebagai morfem yang sama.

\section{Prinsip IV}

Bentuk yang termasuk dalam prinsip ini ditemukan pada kata benda tunggal, kata benda jamak, dan kata kerja present dan past. Perhatikan tabel berikut.

Tabel 6 Kata Benda Tunggal dan Jamak

\begin{tabular}{llll}
\hline No. & Singular & Plural & Arti \\
\hline 1. & deer & deer & rusa \\
\hline 2. & fish & fish & ikan \\
\hline 3. & swine & Swine & babi \\
\hline
\end{tabular}

Dalam bahasa Inggris penanda jamak biasanya ditandai dengan $\{-\mathrm{s}\} /\{-\mathrm{es}\}$. Kata deer, fish, dan swine ditandai dengan kekosongan, yaitu tidak ditandai $\{$-s $\} /\{$-es $\}$ pada bentuk jamaknya. Bentuk tersebut merupakan morfem zero.
Tabel 7 Kata Kerja Present dan Past

\begin{tabular}{llll}
\hline No. & $\begin{array}{l}\text { Present } \\
\text { (V1) }\end{array}$ & $\begin{array}{l}\text { Past } \\
\text { (V2) }\end{array}$ & Arti \\
\hline 1. & beset & beset & menyerang \\
\hline 2. & bet & bet & bertaruh \\
\hline 3. & broadcast & broadcast & menyiarkan \\
\hline 4. & burst & burst & meletus \\
\hline 5. & cut & cut & memotong \\
\hline 6. & hurt & hurt & menyakiti \\
\hline 7. & let & let & membiarkan \\
\hline 8. & outbid & outbid & $\begin{array}{l}\text { menawar } \\
\text { lebih tinggi }\end{array}$ \\
\hline 9 & put & put & meletakkan \\
\hline 10. & read & read & membaca \\
\hline 11. & reset & reset & memasang \\
& & & lagi \\
\hline 12. & shed & shed & mencucurkan \\
\hline 13. & shut & shut & menutup \\
\hline 14. & slit & slit & membelah \\
\hline 15. & upset & upset & mengganggu \\
\hline
\end{tabular}

Dalam bahasa Inggris kata kerja lampau biasanya ditandai $\{-d\} /\{-e d\}$. Namun, bentuk kata kerja past atau lampau beset, bet, broadcast, burst, cut, hurt, let, outbid, put, read, reset, shed, shut, slit, dan upset ditandai dengan kekosongan. Kekosongan itu merupakan morfem yang disebut morfem zero.

\section{Prinsip V}

Prinsip ini ditemukan pada bentuk homonim. Prinsip ini berhubungan dengan semantik (makna) pada bentukbentuk yang homofon berdasarkan persyaratan (1) bentuk-bentuk homofon dengan makna yang jelas berbeda merupakan morfem yang berbeda dan (2) bentuk-bentuk homofon dengan makna yang berhubungan merupakan morfem yang sama apabila kelas-kelas makna disejajarkan dengan perbedaan distribusi, tetapi dapat pula merupakan morfem yang berbeda apabila kelas-kelas makna tidak disejajarkan oleh perbedaan distribusi. Perhatikan tabel berikut. 
Tabel 8 Homonim

\begin{tabular}{llll}
\hline No. & Kata & \multicolumn{2}{c}{ Arti } \\
\hline 1. & bear & beruang & menderita \\
\hline 2. & book & buku & memesan \\
\hline 3. & can & dapat & kaleng \\
\hline 4. & cast & melemparkan & cetakan \\
\hline 5. & cover & penutup & sampul \\
\hline 6. & kind & baik & jenis \\
\hline 7. & lie & berbohong & berbaring \\
\hline 8. & like & seperti & suka \\
\hline 9. & light & lampu & ringan \\
\hline 10. & mine & milikku & ranjau \\
\hline 11. & second & kedua & detik \\
\hline 12. & fly & terbang & lalat \\
\hline 13. & full & penuh & kenyang \\
\hline 14. & great & besar & hebat \\
\hline 15. & hot & panas & pedas \\
\hline 16. & iron & besi & setrika \\
\hline 17. & fish & ikan & mengail \\
\hline
\end{tabular}

Dalam homonim terdapat bentuk-bentuk yang sebunyi, tetapi memiliki makna yang berbeda. Kata bear yang dapat bermakna beruang dan menderita merupakan morfem yang berbeda. Demikian pula kata book yang bermakna buku dan memesan juga merupakan dua morfem yang berbeda. Pada data nomor 17, kata fish memiliki makna ikan dan kata kerja mengail. Perbedaan makna disejajarkan dengan perbedaan distribusi. Yang pertama adalah kata benda dan yang kedua adalah kata kerja. Homonim merupakan morfem yang sama apabila mempunyai makna yang sama atau berhubungan dan mempunyai kelas-kelas makna yang disejajarkan oleh perbedaan distribusi. Morfem merupakan morfem yang berbeda jika mempunyai makna yang berbeda dan mempunyai kelas-kelas makna yang tidak disejajarkan oleh perbedaan distribusi.

\section{Prinsip VI}

Bentuk yang termasuk dalam prinsip ini adalah morfem bebas dan morfem terikat dengan syarat (1) berdiri sendiri, (2) dalam beberapa kombinasi yang setidaknya satu di antara satuan yang digabungkan terjadi secara terpisah atau dalam kombinasi lain, dan (3) dalam kombinasi tunggal asal unsur yang digabungkan dapat berdiri sendiri atau dalam kombinasi lain dengan konstituen yang tidak unik. Perhatikan tabel berikut.

Tabel 9

Morfem Bebas dan Morfem Terikat

\begin{tabular}{llll}
\hline No. & Kata & $\begin{array}{l}\text { Morfem } \\
\text { Bebas }\end{array}$ & $\begin{array}{l}\text { Morfem } \\
\text { Terikat }\end{array}$ \\
\hline 1. & fluently & fluent & $-l y$ \\
\hline 2. & quickly & quick & $-l y$ \\
\hline 3. & calmly & calm & $-l y$ \\
\hline 4. & nicely & nice & $-l y$ \\
\hline 5. & sadly & sad & $-l y$ \\
\hline 6. & finally & final & $-l y$ \\
\hline 7. & advised & advise & $-d$ \\
\hline 8. & called & call & $-e d$ \\
\hline 9. & offered & offer & $-e d$ \\
\hline 10. & prayed & pray & $-e d$ \\
\hline 11. & finished & finish & $-e d$ \\
\hline 12. & brushes & brush & $-e s$ \\
\hline 13. & boxes & box & $-e s$ \\
\hline 14. & photos & photo & $-s$ \\
\hline 15. & cheaper & cheap & $-e r$ \\
\hline 16. & shortest & short & $-e s t$ \\
\hline 17. & discontinue & continue & dis- \\
\hline 18. & dislike & like & dis- \\
\hline
\end{tabular}

Berdasarkan tabel 9, morfem dapat dipisahkan jika terjadi pada kondisi sebagai berikut. Bentuk fluent, quick, calm, nice, sad, final, advise, call, offer, pray, finish, brush, box, photo, cheap, short, continue, dan like adalah bentukbentuk yang diidentifikasi sebagai morfem terpisah karena dapat berdiri sendiri. Morfem-morfem tertentu tidak pernah muncul secara terpisah, seperti bentuk $\{-l y\}$ pada rangkaian kata fluently, quickly, calmly, nicely, sadly, dan finally. Namun, bentuk $\{-l y\}$ dapat diidentifikasi sebagai morfem karena unsur-unsur yang memunculkannya dapat ditemukan secara terpisah, yaitu fluent, quick, calm, nice, sad, dan final. Kondisi kedua tidak mensyaratkan bahwa semua elemen yang bergabung memiliki kemunculan independen, tetapi setidaknya satu bentuk dalam deret struktural tersebut memiliki 
kapasitas kemunculan dalam isolasi atau dalam kombinasi lainnya.

Bentuk yang berakhiran $\{-e d\},\{-s\}$, $\{$-es\}, \{-er\}, dan $\{$-est $\}$ dapat diidentifikasi sebagai morfem karena unsur-unsur yang memunculkannya dapat ditemukan secara terpisah, yaitu advise, call, offer, pray, finish, brush, box, photo, cheap, dan short. Demikian pula kata dislike dan discontinue. Awalan \{dis-\} dapat diidentifikasi sebagai morfem karena unsur-unsur yang memunculkannya dapat ditemukan secara terpisah, yaitu like dan continue. Namun, awalan \{dis-\} tidak dapat berdiri sendiri dan merupakan morfem terikat, sedangkan satuan like dan continue dapat berdiri sendiri dan merupakan morfem bebas.

\section{PENUTUP}

Berdasarkan analisis dapat disimpulkan bahwa terdapat beberapa bentuk morfem yang dapat diklasifikasi berdasarkan enam prinsip pengenalan morfem tersebut. Berdasarkan hasil klasifikasi tersebut dapat disimpulkan bahwa morfem dapat diidentifikasi berdasarkan bentuk kata, kelas kata, dan makna yang muncul. Hal itu sangat membantu untuk mengidentifikasi satuan morfem dalam kajian morfologi.

Prinsip pengenalan morfem tidak hanya dikaji dalam bahasa Inggris, tetapi oleh semua bahasa. Oleh karena itu, penulis menyarankan para peneliti mengkaji prinsip pengenalan morfem dari bahasa atau sumber data yang berbeda.

\section{DAFTAR PUSTAKA}

Achmad, H.P. and Abdullah, A. (2012). Linguistik Umum. Jakarta: Erlangga.

Ba'dulu, A. M. (2005). Morfosintaksis. Jakarta: Rineka Cipta.
Bauer, L. (2007). The Linguistics Student's Handbook. Edinburgh: Edinburgh University Press.

Budiarti, A. (2012). Interferensi Bahasa Indonesia ke dalam Bahasa Inggris pada Abstrak Jurnal Ilmiah. Bahasa dan Seni, 41(1).

Chaer, A. (2003). Linguistik Umum. Jakarta: Rineka Cipta.

Djajasudarma, T. F. (2010). Metode Linguistik. Bandung: PT Refika Aditama.

Gleason, H. A. (1995). An Introduction to Descriptive Linguitics. London: Holt, Rinehart and Winston.

Katamba, F. (1993). Morphology. New York: St. Martin Press. https://doi.org/10.1007/978-1-34922851-5

Keraf, G. (1991). Tata Bahasa Rujukan Bahasa Indonesia. Jakarta: Grasindo.

Lyons, J. (1968). Introduction to Theoretical Linguistics. Cambridge: Cambridge University Press. https://doi.org/10.1017/CBO97811 39165570

Mahsun. (2017). Metode Penelitian Bahasa: Tahapan, Strategi, Metode, dan Tekniknya. Jakarta: Raja Grafindo Persada.

Mark Aronoff, K. F. (2005). What is Morphology? Oxford: Blackwell Publishing.

Nida, E. (1949). Morphology The Descriptive Analys of Words. Michigan: University of Michigan Press.

Puspita, Y. (2020). Pembelajaran Morfem dan Alomorf dalam Bahasa Indonesia. Makalah tanpa tahun.

Samsuri. (1994). Analisis Bahasa. Jakarta: Erlangga.

Sudaryanto. (2018). Metode dan Aneka Teknik Analisis Bahasa: Pengantar Penelitian Wahana Kebudayaan 
Secara Linguistis. Yogyakarta: Sanata Dharma University Press.

Suherman. (2018). Top Grammar: A

Guide to Write English. Kediri: CV Resonansi Ilmu.

Tarigan, H. G. (1988). Pengajaran Morfologi. Bandung: Angkasa.

Verhaar, J. W. M. (2016). Asas-asas

Linguistik Umum. Yogyakarta: Gadjah Mada University Press.

Yule, G. (2016). The Study of Language. Cambridge: Cambridge University Press. 